\title{
包括的凝固検查を用いた血友病診療の発展
}

野上恵嗣*

\section{Recent advance in hemophilia practice utilizing the comprehensive coagulation function evaluation}

Keiji NoGAMI

要約：血友病は当該因子活性レベルが臨床的重症度と相関を示すため, 活性 レベル $<1 \mathrm{IU} / \mathrm{dL}$ は重症，1～5 IU/dL は中等症， $>5 〜<40 \mathrm{IU} / \mathrm{dL}$ は軽症と分類 される。一方, 活性レベルと臨床症状が相関しない症例もしばしば経験する. この乘離の要因の 1 つに, 凝固 1 段法による因子活性が生体内全体の止血凝 固能を十分には反映しないことが考えられる。現在では細胞基盤型凝固モデ ルで生体内凝固機序が説明されており，この概念を反映するような，包括的 な血液凝固機能評価の測定法が発展している. トロンボエラストグラフィー, 凝固波形解析，トロンビン生成試験がその代表である。コンピューター化さ れ, 凝固過程の定性的評価, さらに算出したパラメータによる定量的評価も 可能である。包括的凝固評価により，患者本来の凝血学的止血能を把握し， また出血の重症度予測や止血管理の方針や，長期にわたる止血方針も立案す ることも可能と考えられている。ささらに先天性血友病のみならず，重篤な出 血症状を呈する後天性血友病 $\mathrm{A}$ および他の凝固障害症の診断や治療効果判 定などにも多く応用されている. 今後, 止血関連研究や治療止血効果の評価 法の中心的役割としてますます発展していくことが期待される.

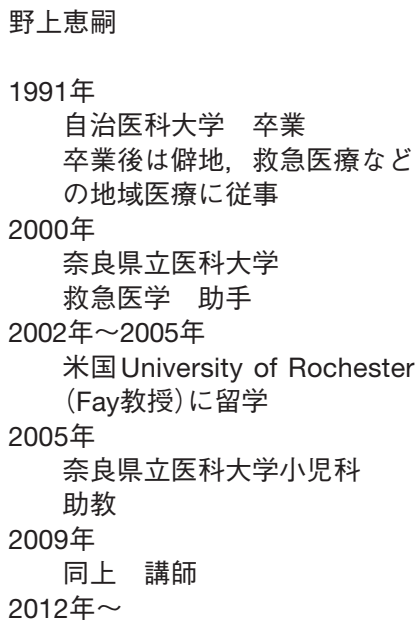

同上 准教授

Key words: hemophilia A, factor VIII, inhibitor, global coagulation assay

\section{1. 緒言}

血友病は血液凝固第 VIII 因子 (FVIII) および第 IX 因子 (FIX)の遺伝子異常による量的質的異常症であ り，それぞれを血友病 $\mathrm{A}$, 血友病 $\mathrm{B}$ という。先天性 凝固障害症の中では最も頻度の高い疾患である。両 型の血友病の臨床的病態はほぼ同じであり，血液凝 固反応機序の中軸である内因性第 X 因子 $(\mathrm{FX})$ 複合 体での FX 活性化反応の障害により，関節内および 筋肉内を中心とした重篤な出血症状を呈する。血友

\footnotetext{
*責任者連絡先：

奈良県立医科大学小児科

干 634-8522 奈良県橿原市四条町 840

Tel: 0744-29-8881, Fax: 0744-24-9222

E-mail: roc-noga@naramed-u.ac.jp
}

病診療において，臨床的重症度の評価や当該因子製 剂投与による止血効果の評価のために因子活性の測 定が一般的に行われている。一方, 臨床の場で因子 活性のみの評価では困難な症例も存在する。このた め，単一因子のみでの評価だけでなく，凝固機能を 包括的に評価する測定法も近年注目されており，従 来の因子活性測定法と包括的凝固機能測定法を組み 合わせることにより，患者個々の凝血学的止血能を さらに把握することが可能となっている。本稿では, 包括的凝固機能測定の現状と, これらを取り入れた 血友病診療および今後の発展について述べる。 


\section{2. 包括的凝固機能評価法}

\section{1）発展までの背景}

血友病は FVIII および FIX 活性レベルが臨床的重 症度と相関を示す。凝固一段法で測定される因子活 性において, <1 IU/dL は重症，1～5 IU/dL は中等症， $>5 \sim<40 \mathrm{IU} / \mathrm{dL}$ は軽症と定義される ${ }^{1)}$ 。ところが実際 には, 重症血友病と診断された症例でも出血症状が 極めて軽度である場合，逆に中等症または軽症血友 病と診断された症例でも，重度な出血症状を呈する 場合も臨床の現場でしばしば経験する2 に因子活性と臨床的重症度の乘離には様々な要因が 考えられ，一つに測定方法がある。凝固一段法では 非生理的条件下での活性化部分トロンボプラスチン 時間 (aPTT) 測定を用いるため, 本法にて求められ る FVIII および FIX 活性のみで生体内全体の凝固止 血能を十分に反映する考えに限界があるかもしれな い。また，他の凝固因子により臨床的重症度に影響 を及ぼすことも知られている21.

一方, 血友病患者の止血治療において, 繰り返す 凝固因子製剂の補充により, 当該因子の同種抗体 (インヒビター)が出現する。当該因子製剤の補充療 法の止血効果は減弱〜消失するため, バイパス止血 製剤により止血管理が行われるが，その際，因子活 性值による凝血学的評価は困難となる。これらの状 況において，因子活性に代わり，包括的凝固止血能 を評価できる測定法が血友病専門施設において従来 から行われてきた。現在, トロンボエラストグラ フィー, 凝固波形解析, トロンビン生成試験が発展 してきている3).いずれの測定法もコンピューター 化され, 凝固過程の定性的評価, さらに種々の算出 パラメー夕を用いた定量的評価が可能である.

\section{2）包括的凝固機能検査法}

(a)トロンボエラストグラフィー (thromboelastography: TEG)

TEG は凝固過程中での凝固の粘性や弾性変化を モニタリングして, 凝固過程を波形として描出する ことにより，凝固機能を評価する方法である。古く から凝固・線溶・血小板機能の評価として利用され てきた，本法は全血で測定可能であるが，再現性が 悪く，また同時に多数の検体を測定することが困難 であった。そこで，TEGの改良型である ROTEM (rotational thromboelastometry)が近年開発され，コン ピューター化されることにより, clotting time $(\mathrm{CT})$, clot formation time (CFT), maximum clot firmness ( $\mathrm{MCF})$ の種々のパラメータの算出や解析が可能と なった(図1)。さらに、リアルタイムの生波形を処 理することにより, 凝固波形, 最大凝固速度, 最大 凝固速度時間などのパラメータの算出が可能で, 定 性かつ定量的な解析がさらに可能となった。 測定方 法は, $\mathrm{CaCl}_{2}$ 添加 (NATEM), カオリンまたはエラジン 酸添加(INTEM), イノビン ${ }^{\circledR}$ 添加 (EXTEM)があり, 用途に合わせ施行される4).

(b) 凝固波形解析 (clot waveform analysis: CWA)

一般的な凝固機能検査として，プロトロンビン時 間 $(\mathrm{PT})$ と活性化部分トロンボプラスチン時間 (aPTT) を用いるが，いずれの検査も $\mathrm{CaCl}_{2}$ 添加から凝固開 始までの凝固前相のみを評価している。しかしなが ら凝固反応とは凝固前相, 凝固開始後に一定速度で フィブリン形成を生じる凝固相, 凝固反応が終了後 に生じる凝固後相に至るすべての過程を通じて進行 していくため，全過程を評価することが必要である。 CWA は通常の PT や aPTT 測定反応系のフィブリン 形成過程に技ける血漿サンプルの透過度の変化をモ ニタリングし, 凝固の全過程を凝固波形として描出 することができる，得られたデータのコンピュー ター解析を行い, 凝固波形を一次微分して凝固速 度, 二次微分して凝固加速度を算出し, その最大值 をそれぞれ最大凝固速度 $(|\min 1|)$, 最大凝固加速度 $(|\min 2|)$ としてパラメータが得られる(図 2)。この凝 固波形とパラメータにより凝固の動的過程を把握し, 定量的に評価することができる5)。なお現在, CWA が可能である測定機器も増えてきている ${ }^{6}$.

(c)トロンビン生成試験 (thrombin generation assay: TGA)

トロンビンが血液凝固反応系の中心的存在である ため, 内因性のトロンビン生成量を測定することは, 凝固機能を包括的に評価することにつながる。近年 開発された calibrated automated thrombogram $(\mathrm{CAT})$ シ ステムは蛍光発色基質の使用で脱フィブリン処理が 不要であり, 多検体の測定や自動的にリアルタイム な測定が可能である7). TGA はフィブリン形成の前 段階のトロンビン生成を高感度に検出することがで き，フィブリノゲンに影響されない。また，本法は 


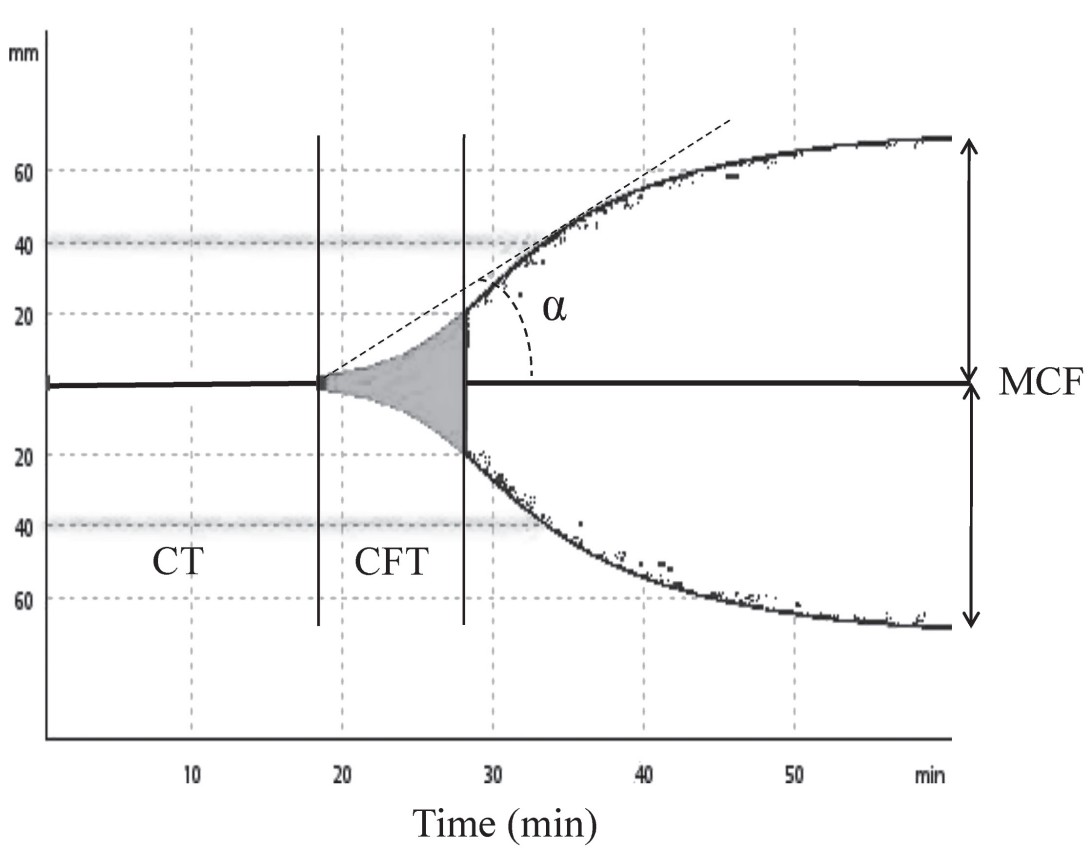

図 1 正常血漿におけるROTEM 波形

各パラメータ CT : clotting time, CFT : clot formation time, MCF : maximum clot firmness， $\alpha$ : $\alpha$ 角度，を表す。

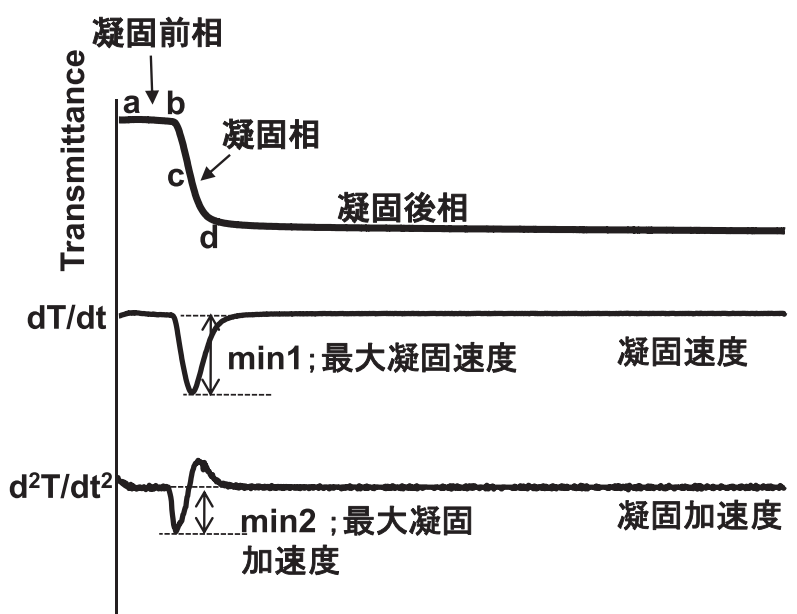

Time (t)

図 2 正常血漿における凝固波形解析 (CWA) 正常血漿から得られる凝固波形とそのパラメータを示す.

乏血小板血漿 (PPP)のみならず多血小板血漿 (PRP) の検体でも測定可能であり，血小板存在下にて生理 的に近い状態での凝固反応も評価できる，血液凝固 機序の概念として, 組織因子 $(\mathrm{TF})$ 存在下で活性型第 VII 因子 (FVIIa)により凝固反応が始動し, 微量のト ロンビンが産生後, 内因性 FX 複合体およびプロト ロンビン複合体反応が増幅されてトロンビンバース

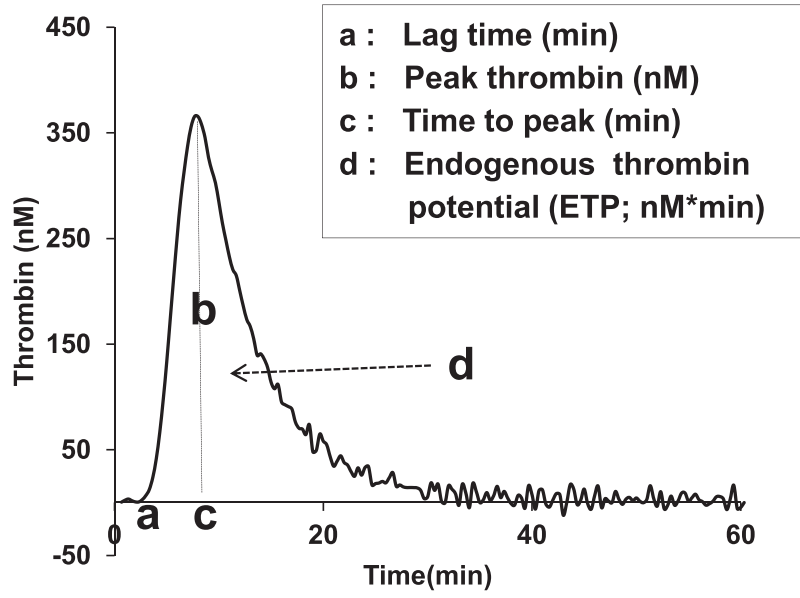

図 3 正常血漿におけるトロンビン生成試験(TGA) 正常血漿から得られるトロンボグラムとそのパラメータ を示す。

トが起こり多量のフィブリンが生成される ${ }^{8)}$ という 細胞基盤型凝固が現在支持されており，TGAによ る凝固機能評価は本機序に基づかれている。 TGA で は $\mathrm{TF}$ 惹起 (トリガー)にて凝固反応を開始させ，凝 固過程におけるトロンビン生成率をモニタリングし て波形として描出する(図 3)。 Lag time(潜時), peak thrombin(トロンビン頂值), time to peak(ピークに達 
正常血漿

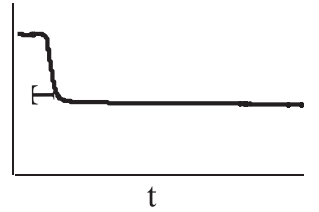

症例 1

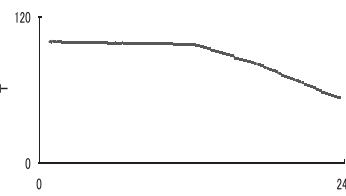

症例 2

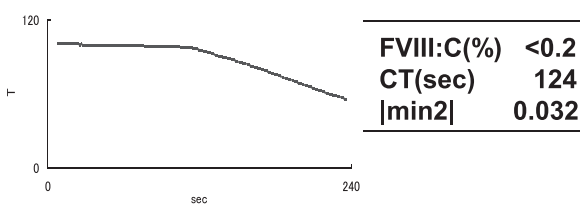

FVIII:C(\%) 87.0

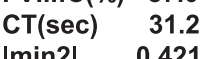

|min2|

0.421

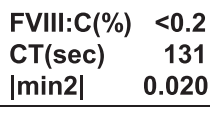

症例 3

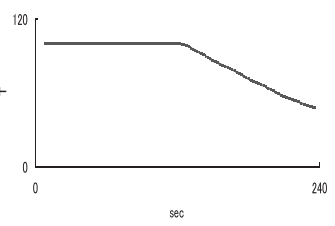

FVIII:C(\%) $\quad 0.3$

CT(sec) $\quad 114$

|min2| 0.049

症例 4

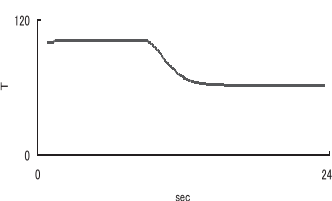

FVIII:C(\%) $\quad 0.6$

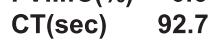

Imin2| 0.126

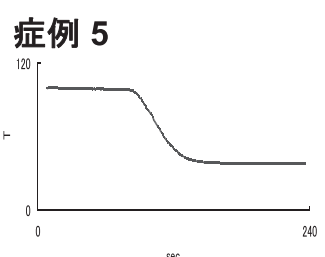

FVIII:C(\%) $\quad 0.6$

CT(sec) $\quad 85.2$

|min2| 0.141

図 4 重症血友病 A 患者の aPTT トリガーによる CWA

凝固一段法による FVIII 活性 <1 IU/dL の血友病 A 患者血漿の凝固波形を示す。症例に より凝固波形およびパラメータが異なっていることがわかる.

(文献 9 から引用一部改変)

する時間), ETP(総トロンビン生成量)のパラメータ が算出でき，より定量的に評価することができる.

\section{3. 包括的凝固機能解析の実際}

\section{1）微量 FVIII 活性の評価}

FVIII および FIX 活性の測定限界は $1 \mathrm{IU} / \mathrm{dL}$ とされ る。しかし，興味深いことに FVIII 活性 $<1 \mathrm{IU} / \mathrm{dL}$ の 血友病 $\mathrm{A}$ 患者血漿の aPTT 凝固波形解析を行うと, 波形パターンが症例により異なっていた(図 4) ${ }^{9}$. 全 例とも<1 IU/dL 活性であるが, 症例 1 では凝固前相 は長く, 凝固開始後の傾斜も極めて緩徐であるが, 症例 2 から順に凝固前相は短く, 凝固相の傾斜も鋭 くなっており, 重症血友病患者でも凝固機能が異な る症例が存在することを初めて示唆した。 そこで, FVIII 欠乏血漿に順次希釈した遺伝子組換え FVIII を添加した標準検量線を作成し, CWA では $<1.0 \mathrm{IU} /$ $\mathrm{dL}$ の微量 FVIII の検出が可能であり, 検出感度は $<0.2 \mathrm{IU} / \mathrm{dL}$ であった. FVIII 活性 $<1 \mathrm{IU} / \mathrm{dL}$ の重症血友 病 A 患者血漿(32 名)を CWA で解析したところ, 27 名は<0.2 IU/dLであり, $|\min 2|$ も極めて低值であった。
しかし 5 名は $0.2<<1.0 \mathrm{IU} / \mathrm{dL}$ の活性レベルを示した。 さらに 27 名中 24 名の症状は重症であったが, 他の 3 名の症状は軽症であったことから， <0.2 IU/dL の 血友病 $\mathrm{A}$ の大部分が臨床的に重症であるが, 一部 には軽症も存在していた", 10).このことから CWA は微量 FVIII を十分反映できることが示された。

TGA では, TF 惹起 TGA を用いた血友病の凝血 学的評価は多数報告されている。 FVIII 活性は ETP, ピーク值，ピークに達する時間のパラメータと比較 的相関するとされている ${ }^{11)}$. 本法の欠点として, 微 量因子レベルでの測定は不確実であり，CWAに比し 感度が低いことであった。われわれは, 微量 TFに エラジン酸を添加し, 内因系・外因系の両者を反映 させるトリガー試薬(混合法)による TGA を確立し た。本法では, ETP, トロンビンピーク值, ピーク 時間のパラメータが微量 FVIII レベル 0.2〜10 IU/dL の低濃度域と高い相関を示し ${ }^{12)}$, 血友病の凝固機能 評価に極めて有用であるとされている。また， <1 IU/ $\mathrm{dL}$ の重症血友病 $\mathrm{A}$ でもトロンビン生成能に差異を 認める症例も存在していた ${ }^{13)}$. 

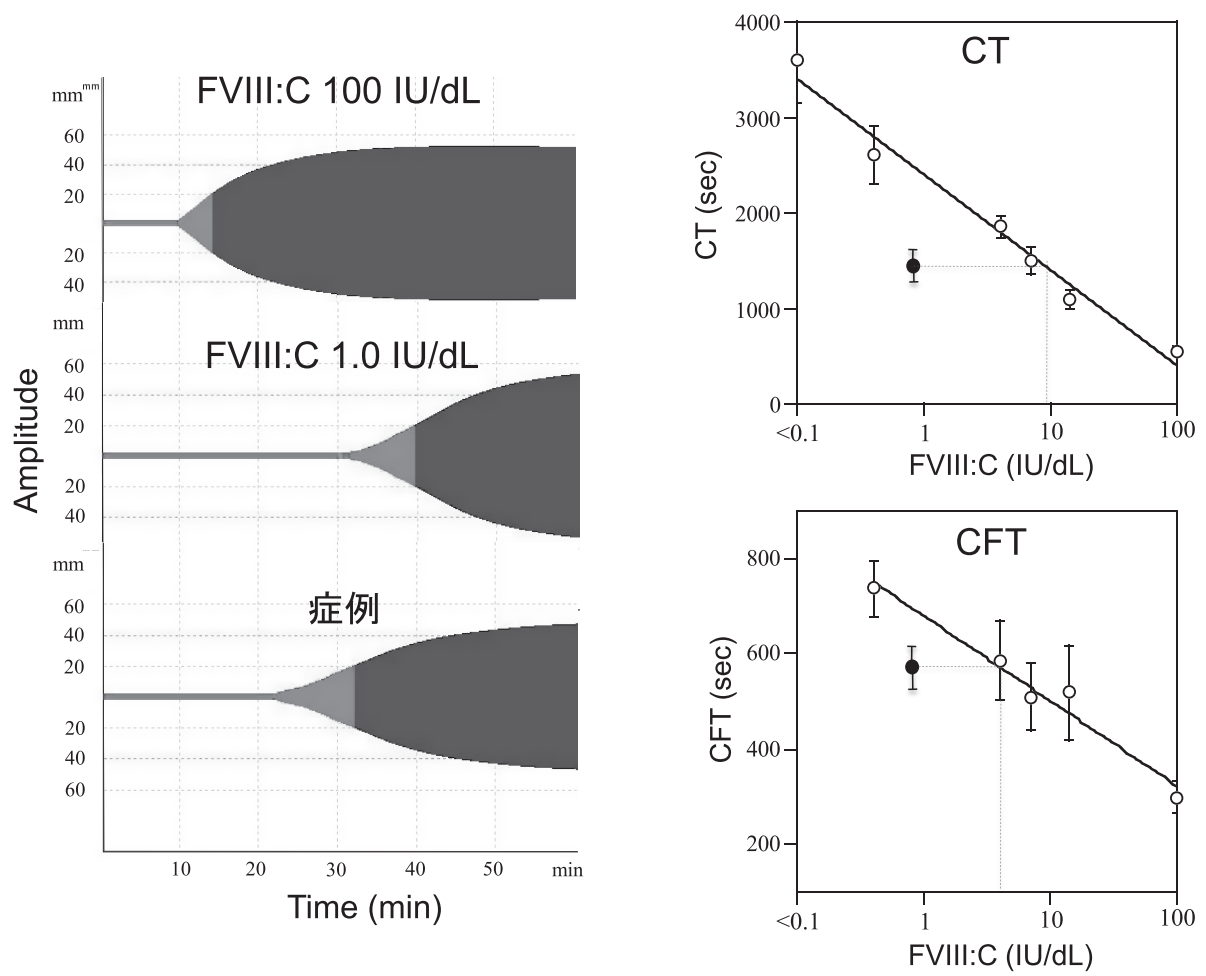

図 5 血友病 A 症例 $(<1.0 \mathrm{IU} / \mathrm{dL})$ の ROTEM とパラメータ

ROTEM 波形から得られた CT や CFT のパラメータが, FVIII : C $1.0 \mathrm{IU} / \mathrm{dL}$ の血友病 A 患者より著明に短縮している。重症血友病 A 患者全血に FVIII 各濃度を添加して得ら れた検体のパラメータの標準曲線 $(\bigcirc)$ から, 症例 $($ ) の凝固止血能は FVIII 活性で 5 $10 \mathrm{IU} / \mathrm{dL}$ 相等を示す.

(文献 14 から引用一部改変)

\section{2）血友病患者の凝血学的評価：概念“Coagulotype”}

われわれは，臨床の場において重症型のみならず 中等症 - 軽症血友病患者の活性とともに包括的凝固 機能評価も同時に行い, 患者本来の凝固止血潜在能 を総合的に評価することにより，将来的な止血(予 防）管理の計画立案の一助としている。われわれは このような患者本来の包括的な凝固止血能を“Coagulotype” と呼んでいる。とくに中等症・軽症血友病は FVIII(FIX) 遺伝子の点変異により生じることが多く, 時に因子活性と包括的凝固能とが異なることも経験 することがある，当科で経験した，重症血友病 A で あるが Coagulotype では軽症型を示した症例を提示 する $(\text { 図 } 5)^{14)}$.

27 歳血友病 $\mathrm{A}(\mathrm{R} 1781 \mathrm{H}$ 点変異)。2 歳時, 前額部 切創の止血困難のため, 精査にて FVIII 活性 $<1 \mathrm{IU} /$ $\mathrm{dL}$ で重症血友病 $\mathrm{A}$ と診断. それ以降, 出血回数が 少なく, FVIII 製剂総投与量も極めて少なく，定期
補充療法を施行されず。最近の FVIII 活性は $<1.0 \mathrm{IU} /$ $\mathrm{dL}$ (凝固一段法), 抗原量は $1.8 \mathrm{IU} / \mathrm{dL}$. 血友病性関 節症はほとんど認めなかった。活性值と臨床症状に 乘離を認めたため, 包括的凝固機能評価を行った. ROTEM では，患者の凝固止血能は FVIII 活性 5 $10 \mathrm{IU} / \mathrm{dL}$ 相等, CWA および TGA でも, $10 \mathrm{IU} / \mathrm{dL}$ 相 等のパラメータを示した。以上から，患者の実際の 凝固潜在能は FVIII 活性 $<1.0 \mathrm{IU} / \mathrm{dL}$ の重症型でなく, Coagulotype で〜 $10 \mathrm{IU} / \mathrm{dL}$ 相等の軽症型レベルを有し ていることがわかった。詳細な検討から $\mathrm{R} 1781 \mathrm{H}$ 点 変異により生じる FX 結合能の増強が, 患者の臨床 的重症度に影響を与えていた。

\section{3）インヒビター保有血友病患者のバイパス止血療 法のモニタリング}

抗凝固因子抗体 (インヒビター) は血友病 $\mathrm{A}$ 患者の $20 \sim 30 \%$, 血友病 B 患者の 3 5\%に出現し, 当該 因子製剤の補充療法の止血効果は減弱〜消失する. 
バイパス止血製剤により止血管理が行われるが，通 常の因子活性による評価は困難になる。しかし，バ イパス止血製剤による止血モニタリングが十分に確 立していないため, 患者の症状, 画像評価や $\mathrm{Hb}$ 值 などで対応されている現状である。 なお，止血モ二 タリングとして ROTEM の包括的機能検査による止 血評価の施行可能な専門施設も少しずつではあるが 増えてきている.

(a)バイパス止血製㓮の不応

以前より, インヒビター保有血友病 $\mathrm{A}$ 患者へのバ イパス止血療法における不応例についての報告は散 見されていたが, 詳細な機序は明らかでなかった。 最近われわれも，止血管理中での活性化プロトロン ビン複合体製剂 ( $\mathrm{aPCC})$ の連日投与による効果減弱を 繰り返す小览重症血友病 $\mathrm{A}$ 患者を経験した ${ }^{15,16)}$ 。当 科ではバイパス止血療法の止血モニタリングとして ROTEM を施行しており，本症例において aPCCの 不応状態を早期に把握することにより，遺伝子組換 え FVIIa 製片に速やかに切り替えることができ，良 好な止血管理を行うことができた。なお本機序とし て aPCC 投与により増加する組織因子経路インヒビ ター(TFPI)の増加によるトロンビン生成能の低下 であることが TGA を用いた実験から明らかになっ た ${ }^{16)}$.

(b)CWAを用いたバイパス止血療法の止血モニ夕 リング

わが国でもバイパス止血療法の止血モニタリング としてROTEM が少しずつ普及してきているが，測 定には全血サンプルが必要であり, サンプル採取後 4〜5 時間以内に施行しなければならない。一方, TGA は海外では利用されており, サンプルは血漿で あるが，機器が高価であり，また手技が煩雑である ため沉用性がそしい。そこでわれわれは，汎用性の 高いCWA を用いたバイパス止血療法の止血モニ夕 リングの有用性を報告した。 aPTTによる CWA はバ イパス止血製剤の効果を十分に反映できないため, 微量 TFにエラジン酸を添加し, 内因系・外因系の 両者を反映させるトリガー試薬(混合法)による CWA を確立した ${ }^{17)}$ 。混合法を用いることにより， aPCC お

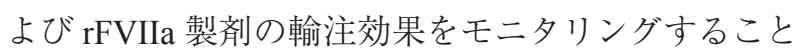
が可能となった(図 6A, B)。また，本法を用いてパ ラメータ $(\mathrm{CT},|\min 2|)$ をニタリングすることによ
り，周術期止血管理を良好に行うことができた ${ }^{17)}$.

\section{4）後天性血友病の凝血学的評価}

後天性血友病 A は健常人に突然発症する抗 FVIII 自己抗体が原因で非常に重篤な出血を引き起こす疾 患であり，FVIII 活性值やインヒビター力価は臨床的 重症度における病態を全く反映しないとされる ${ }^{18)}$. TGAにより, 同活性レベルを有する後天性血友病 A は先天性血友病 A より peak thrombin, time to Peak, ETP で有意に低下すること，すなわち凝固機能が著 しく障害されていることがわかった(図 7) ${ }^{13)}$. 後天 性血友病 A の FVIII 阻害様式に違いはあるものの, $\mathrm{FVIII/IgG}$ 複合体の存在が, FXa 複合体生成を阻害 することにより，トロンビン生成を強く障害させて いることが明らかになった ${ }^{13)}$ ，また，後天性血友病 Aの鑑別診断として, 抗リン脂質抗体症候群 (APS) もしくはループスアンチコアグラント陽性 (LA+) 症 例がある。凝固一段法では診断に苦慮することが多 い、その際，TGAを用いて lag time はAPSまたは LA+症例では正常より延長していることが多いため, われわれは診断の一助としている ${ }^{19)}$.

\section{4. 最近のトピックス}

\section{トロンビン・プラスミン生成試験 (thrombin/plasmin generation assay: T/P-GA)}

T/P-GA は, TGA でのトリガー試薬である TF/リン 脂質にさらに組織型プラスミノーゲンアクチベータ (t-PA)を添加し，トロンビンとプラスミンそれぞれ の蛍光発色基質を反応させることで, 凝固・線溶機 能を同時に評価する測定法である ${ }^{20)}$ 。本法は，プラ スミン生成が凝固と連動して惹起されることから, 患者血漿中の凝固能のみならず線溶機能を評価しう る. 先天性血友病 $\mathrm{A}$ は, トロンビン生成が低下する がプラスミン生成は正常，FX 欠乏症は，両者共に 低下する。一方フィブリノゲン欠乏およびプラスミ ノゲン欠そ症は, トロンビン生成はほぼ正常だがプ ラスミン生成は認めないことなど，T/P-GA を用いる と凝固と線溶のバランスが崩れていることがわか る. 最近, 後天性血友病 $\mathrm{A} の$ 急性期の重篤な出血症 状時はプラスミン生成も極めて低下しており，患者 の病勢にプラスミン生成の評価が有用であることを 報告している $\left(\right.$ 図 8) ${ }^{21)}$. 
(A)
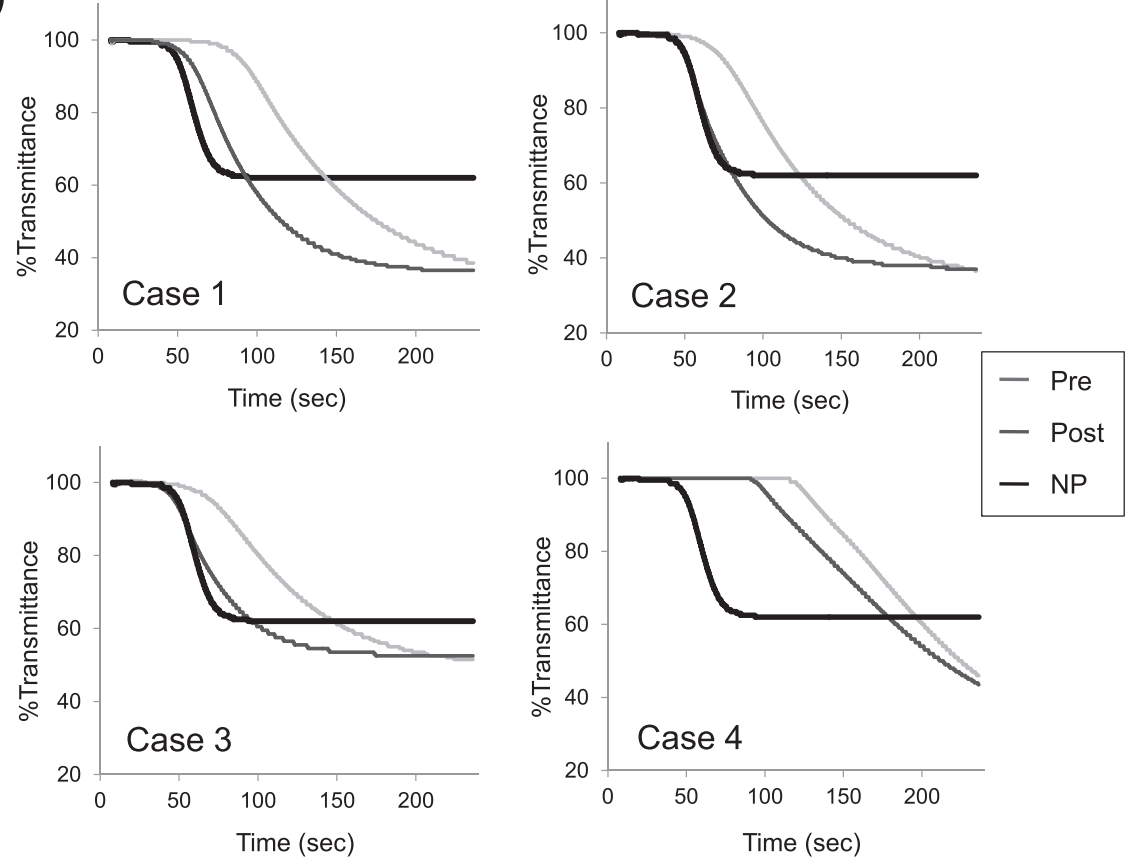

(B)
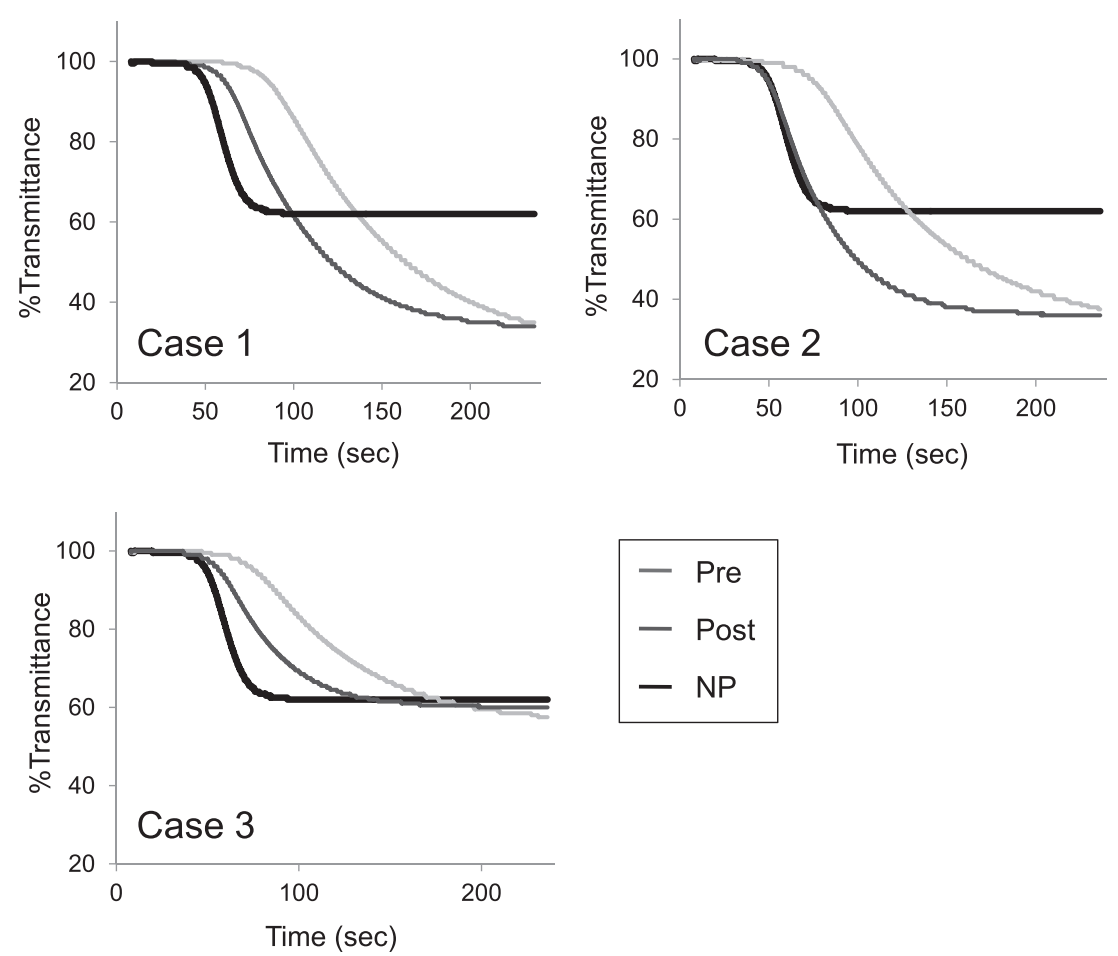

図 6 CWA によるインヒビター保有血友病 A 患者へのバイパス止血製剤の輸注効果の 評価

インヒビター保有血友病 $\mathrm{A}$ 患者へのバイパス止血製剤 $(\mathrm{rFVIIa}(\mathrm{A}), \operatorname{aPCC}(\mathrm{B}))$ 輸注前後 の患者血漿に打ける TF/エラジン酸惹起 CWA による凝固波形を示す。臨床症状と一致 しており，両製剂の止血効果評価として CWA による止血モニタリングは有用である. (文献 17 から引用一部改変) 
中等症血友病 $A$

(FVIII:C 2.0 U/dL)

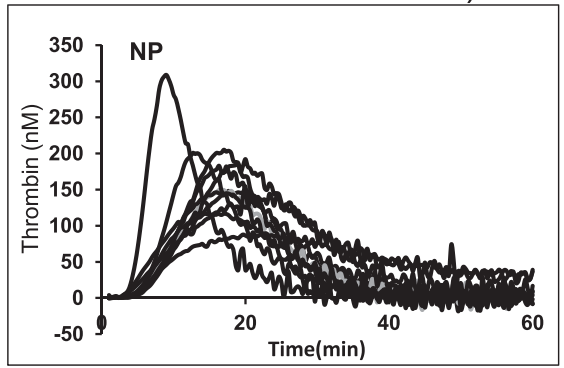

Peak thrombin

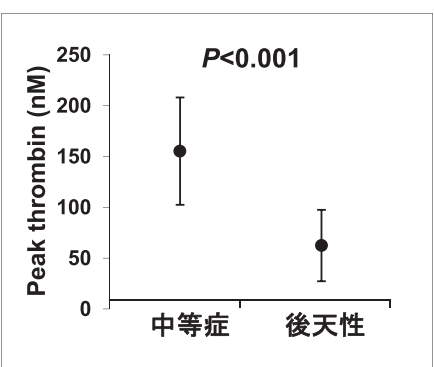

後天性血友病A

(FVIII:C 2.0 U/dL)

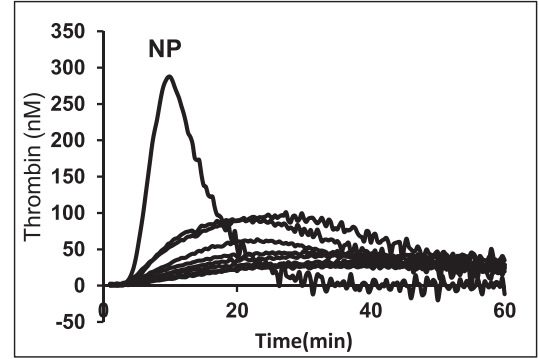

Time to Peak

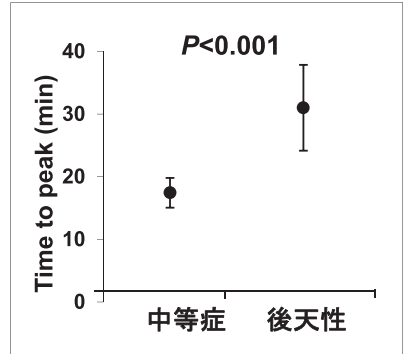

図 7 先天性中等症血友病 $\mathrm{A}$ と後天性血友病 A のトロンビン生成試験

(A) ともに FVIII 活性〜2 IU/dL レベルの中等症血友病 A と後天性血友病 A の患者血漿 のトロンビン生成能を示す。（B）TGA から得られたパラメータを示す。後天性血友病 A の凝固止血能が, FVIII 活性の同レベルの中等症先天性血友病 Aよりも著明に低下 していることがわかる。

(文献 13 から引用一部改変)

正常血漿

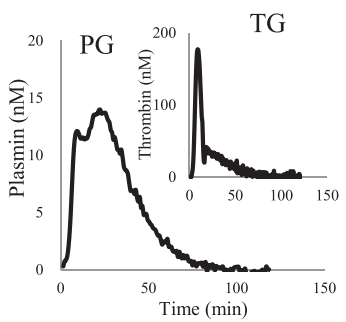

day 56

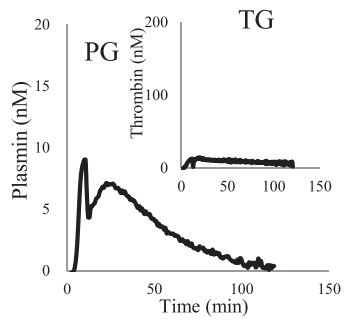

day 0

day 20 day 28

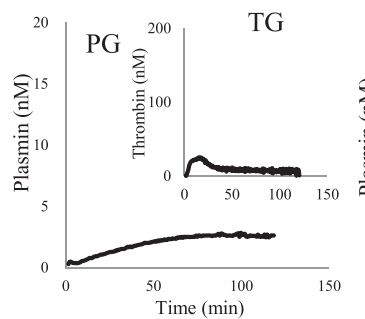

day 69
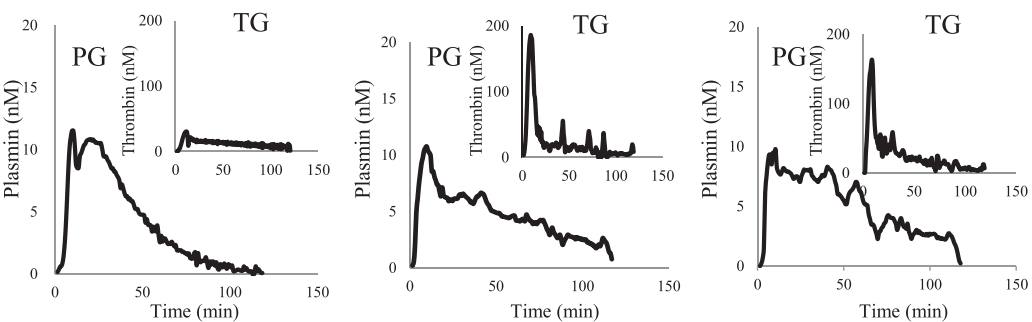

図 8 後天性血友病 $\mathrm{A}$ 患者のトロンビン・プラスミン生成能の経時的変化

症例のトロンビン生成 $(\mathrm{TG})$ とプラスミン生成 $(\mathrm{PG})$ の経時的変化を示す. Day0 は入院当日を示す. 急性期の重篤な出血症状時はプラスミン生成も極めて低下しており, 病勢にプラスミン生成の評価 が有用である。

(文献 21 から引用一部改変) 


\section{5. 終わりに}

因子活性と包括的凝固機能測定を組み合わせるこ とにより，血友病患者の本来の凝血学的止血能の把 握をすることが可能であると思われる。さらに、こ れら種々の組み合わせの評価を用いることにより， 患者個々の出血の重症度の予測や今後の止血管理の 方針，さらに長期にわたる止血方針も立案すること も可能であろう. 今後, 症例数を蓄積していき, 包 括的凝固機能評価が臨床の場でより有用であること を示していく予定である。

\section{著者の利益相反 $(\mathrm{COI})$ の開示 :}

臨床研究 (治験) (中外製薬),

研究費 (受託研究, 共同研究, 寄附金等) (Novo Nordisk, Shire, Biogen, Chugai)

\section{文献}

1) White GC, Rosendaal F, Aledort LM, Lusher JM, Rothschild C, Ingerslev J; Factor VIII and Factor IX Subcommittee: Definitions in hemophilia. Recommendation of the scientific subcommittee on factor VIII and factor IX of the scientific and standardization committee of the International Society on Thrombosis and Haemostasis. Thromb Haemost 85, 560; 2001.

2) Nogami K, Shima M: Phenotypic heterogeneity of hemostasis in severe hemophilia. Semin Thromb Hemost 41: 826-831, 2015.

3）野上恵嗣：血液凝固の動的把握と血友病診療の進歩. 血栓止血誌 25; 371-379; 2014.

4) Nogami K. The utility of thromboelastography in inherited and acquired bleeding disorders. Br J Haematol 174: 503514; 2016.

5) Shima M, Matsumoto T, Fukuda K, Kubota Y, Tanaka I, Nishiya K, Giles AR, Yoshioka A: The utility of activated partial thromboplastin time (aPTT) clot waveform analysis in the investigation of hemophilia A patients with very low levels of factor VIII activity (FVIII:C). Thromb Haemost 87 : 436-441, 2002.

6) Shima M, Thachil J, Nair SC, Srivastava A; Scientific and Standardization Committee: Towards standardization of clot waveform analysis and recommendations for its clinical applications. J Thromb Haemost 11: 1417-1420, 2013.

7) Hemker HC, Giesen $P, A l$ Dieri R, Regnault V, de Smedt E, Wagenvoord R, Lecompte T, Béguin S: Calibrated automated thrombin generation measurement in clotting plasma. Pathophysiol Haemost Thromb 33: 4-15, 2003.

8) Hoffman M. A cell-based model of coagulation and the role of factor VIIa. Blood Rev 17(Suppl 1): S1-5, 2003.

9) Matsumoto T, Shima M, Takeyama M, Yoshida K, Tanaka I, Sakurai Y, Giles AR, Yoshioka A: The measurement of low levels of factor VIII or factor IX in hemophilia A and hemophilia B plasma by clot waveform analysis and thrombin generation assay. J Thromb Haemost 4: 377-384, 2006.

10) Shima M, Matsumoto $T$, Ogiwara $K$. New assays for monitoring haemophilia treatment. Haemophilia 14(Suppl 3): 83-92; 2008.

11) Dargaud Y, Béguin S, Lienhart A, Al Dieri R, Trzeciak C, Bordet JC, Hemker HC, Negrier C: Evaluation of thrombin generating capacity in plasma from patients with haemophilia A and B. Thromb Haemost 93: 475-480, 2005.

12) Matsumoto T, Nogami K, Ogiwara K, Shima M: A modified thrombin generation test for investigating very low levels of factor VIII activity in hemophilia A. Int J Hematol 90: 576$582,2009$.

13) Matsumoto $T$, Nogami K, Ogiwara K, Shima M: A putative inhibitory mechanism in the tenase complex responsible for loss of coagulation function in acquired haemophilia A patients with anti-C2 autoantibodies. Thromb Haemost 107: 288-301, 2012.

14) Yada K, Nogami K, Wakabayashi H, Fay PJ, Shima M: The mild phenotype in severe hemophilia A with Arg1781His mutation is associated with enhanced binding affinity of factor VIII for factor X. Thromb Haemost 109: 1007-1015, 2013.

15) Hayashi T, Tanaka I, Shima M, Yoshida K, Fukuda K, Sakurai Y, Matsumoto T, Giddings JC, Yoshioka A: Unresponsiveness to factor VIII inhibitor bypassing agents during haemostatic treatment for life-threatening massive bleeding in a patient with haemophilia A and a high responding inhibitor. Haemophilia 10: 397-400, 2004.

16) Ogiwara $K$, Nogami $K$, Matsumoto $T$, Shima M: Tissue factor pathway inhibitor in activated prothrombin complex concentrates (aPCC) moderates the effectiveness of therapy in some severe hemophilia A patients with inhibitor. Int J Hematol 99: 577-587, 2014.

17) Haku J, Nogami K, Matsumoto T, Ogiwara K, Shima M: Optimal monitoring of bypass therapy in hemophilia A patients with inhibitors by the use of clot waveform analysis. J Thromb Haemost 12: 355-362, 2014.

18）田中一郎, 天野景裕, 瀧正志, 岡敏明, 酒井道生, 白 幡聡, 高田昇, 高松純樹, 竹谷英之, 花房秀次, 日笠聡, 福武勝幸, 藤井輝久, 松下正, 三間屋純一, 吉岡章, 嶋緑倫：わが国における後天性凝固因子インヒビター の実態に関する 3 年間の継続調査. 予後因子に関する 検討. 血栓止血誌 19: 140-153; 2008 .

19) Matsumoto T, Nogami K, Shima M: A combined approach using global coagulation assays quickly differentiates coagulation disorders with prolonged aPTT and low levels of FVIII activity. Int J Hematol 105: 174-183, 2017.

20) Matsumoto T, Nogami K, Shima M: Simultaneous measurement of thrombin and plasmin generation to assess the interplay between coagulation and fibrinolysis. Thromb Haemost 110: 761-768, 2013.

21) Takeyama M, Nogami K, Matsumoto T, Taguchi M, Yada K, Okahashi N, Amano I, Kimura H, Shima M: Possible assessment of coagulation function and haemostasis therapy using comprehensive coagulation assays in a patient with acquired haemophilia A. Haemophilia 23: e46-50, 2017. 